\title{
Impact of enzymatic treatment on the blackcurrant (Ribes nigrum L.) polyphenols in juice and press-residue
}

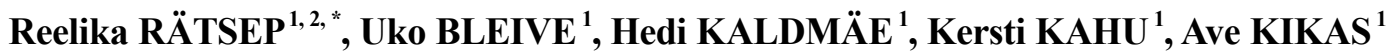 \\ ${ }^{1}$ Polli Horticultural Research Centre, Institute of Agricultural and Environmental Sciences, Estonian University of Life \\ Sciences, Uus 2, Polli, Mulgi parish, Viljandi county, 69108, Estonia \\ ${ }^{2}$ ERA-Chair VALORTECH, Institute of Veterinary Medicine and Animal Sciences, Estonian University of Life \\ Sciences, Kreutzwaldi 56/5, 51014 Tartu, Estonia
}

How to cite this paper: RÄTSEP, R., BLEIVE, U., KALDMÄE, H., KAHU, K., KIKAS, A. (2020) Impact of enzymatic treatment on the blackcurrant (Ribes nigrum L.) polyphenols in juice and press-residue. International Journal of Food Science and Agriculture, 4(1), 43-48.

DOI: $10.26855 /$ ijfsa.2020.03.008

Received: January 2, 2020

Accepted: February 7, 2020

Published: March 2, 2020

*Corresponding author: RÄTSEP, R. Estonian University of Life Sciences, Estonia.

Email: reelika.ratsep@emu.ee

\begin{abstract}
The aim of this study was to determine the effect of pre-pressing enzymatic (pectinase) treatment of blackcurrant mash on the juice yield and content of polyphenolic compounds in juice and press-residue. The fruits of blackcurrant (Ribes nigrum L.) cultivars 'Ben Lomond', 'Pamyati Vavilova' and 'Karri' were collected at the experimental plots of Polli Horticultural Research Centre of Estonian University of Life Sciences $\left(58^{\circ} 7^{\prime} 26^{\prime \prime} \mathrm{N}\right.$, $\left.25^{\circ} 32^{\prime} 43^{\prime \prime E}\right)$. The mash enzyme treatment with Panzym ${ }^{\circledR}$ Univers enzyme preparation was dosed according to the instructions of manufacturer. The mash enzyme treatment improved juice yield depending on the cultivar up to $44.3 \%$ compared to non-treated juice. Though, the contents of polyphenolic compounds varied according to treatment in comparison with freshly frozen berries before pressing, showing up to $18 \%$ decrease of anthocyanin content in enzymatic juice and up to $29 \%$ increase of polyphenols in enzymatic pressresidue. The contents were not significantly different in treated and nontreated juice.
\end{abstract}

\section{Keywords}

fruit processing; juice; by-products; pectinase; phenolic compounds

\section{Introduction}

Blackcurrant (Ribes nigrum L.) is an important fruit crop in Estonia, being cultivated on 578 hectares. Blackcurrant fruits are known to be rich in health promoting bioactive compounds, mostly anthocyanins and other polyphenols. Depending on the cultivar, the fruit technological properties are quite different according to fruit skin thickness, fruit size etc. Mechanical squeezing of blackcurrant mash results in viscous puree due to formation of pectin gel which makes it difficult to extract juice simply by pressing [1,2]. Black currants contain more pectic sugars and by using commercial enzyme during processing releases more pectic material into the juice [1, 2]. In order to overcome the problem, enzymeaided juice pressing is used to increase juice yield, and moreover, to enhance the extraction of bioactive compounds including natural pigments within shorter time into the juice as well $[1,2,3,4,5]$. The most common preparations contain pectinase $[6,7,8]$, cellulase [3] or are used in several combinations [9, 10]. Enzymatic processing has increased the juice yield from 5 to $22 \%$ depending on the preparation used, and enhanced the extraction of phenolic compounds into juice by $4-10$-fold as compared to the non-enzymatic process $[4,10]$.

The impact of enzymatic treatments on juice yield and on the composition of various phenolic compounds in blackcurrant juice has been widely reported $[3,11,12,13,14]$, whereas the range of enzymes on the market is vast. Anthocyanins are the main compounds responsible for the colour of berry juices [15, 16], especially in blackcurrant, which emphasize the importance of their maximum extraction into the juice. However, to our knowledge, the effect of enzyme treatment on different blackcurrant cultivars is not well known as the commercial cultivars differ among the 
cultivation areas. According to literature, a number of various blackcurrant cultivars are tested $[4,11,13,14,17]$, but in many cases only species as such in terms of enzyme treatment for the purpose of juice production have been described [12]. Moreover, the availability of enzyme preparations is wide and the list of investigated commercial enzymes is not exhaustive.

The aim of this study was to determine the effect of pre-pressing enzymatic (pectinase) treatment of blackcurrant fruit mash on the juice yield and content of polyphenols, including anthocyanins in juice and press-residue. Juices from three different cultivars were prepared in laboratory scale.

\section{Materials and methods}

\subsection{Plant material}

About $30 \mathrm{~kg}$ of blackcurrant (Ribes nigrum L.) berries of each cultivar ('Ben Lomond', 'Pamyati Vavilova' and 'Karri') were collected from the experimental plots of Polli Horticultural Research Centre of Estonian University of Life Sciences $\left(58^{\circ} 7^{\prime} 26^{\prime \prime} \mathrm{N}, 25^{\circ} 32^{\prime} 43^{\prime \prime} \mathrm{E}\right)$ and stored frozen at $-20^{\circ} \mathrm{C}$ to maintain their quality until needed for processing.

\subsection{Juice preparation}

Blackcurrant juices were produced in laboratory scale in batches of $15 \mathrm{~kg}$. Prior to maceration berries were thawed 22 $\mathrm{h}$ at room temperature. The berries were crushed using stainless steel Fruit Shark B1600 Shredder $\left(500 \mathrm{~kg} \mathrm{~h}^{-1}, 1.6 \mathrm{kV}\right.$, Czech Republic). Half of the batches were heated in a water bath after which pectinolytic enzyme Panzym ${ }^{\circledR}$ Univers (produced from Apergillus strains) was dosed according to the instructions of the manufacturer $\left(0.16 \mathrm{~mL} \mathrm{~kg}^{-1}\right)$, and the other half was pressed without enzyme treatment. Immediately after 3,5 hours of mash treatment, juice was extracted from the samples by pressing with stainless steel Speidel hydropress $(20 \mathrm{~L}$ capacity) in which the pressure was raised up to 3 bars $\left(3 \mathrm{~kg} \mathrm{~cm}^{-2}\right)$ on the third minute of processing and was held at the same level during the pressing procedure for 10 minutes. The treatments were as follows: non-enzyme-treated juice (NEJ) - untreated blackcurrant mash was pressed directly into juice, and enzyme-treated juice (EJ) - mash was treated prior to juice pressing with enzyme Panzym ${ }^{\circledR}$ Univers $(0.16 \mathrm{~mL} / \mathrm{kg}$ ); non-enzyme-treated press-residues (NER) and enzyme-treated press-residues (ER) were collected accordingly. All the juice and press-residue samples were collected immediately after the pressing procedure and analysed on the same day.

\subsection{Measurements and analysis}

The juice yield and proportion of press-residues were determined by weighing and are given as percentage (\%). Dry matter of juice samples was determined using digital moisture analyser Precisa EM 120-HR (Precisa Gravimetrics AG, Dietikon, Switzerland). Soluble solids content ( ${ }^{\circ}$ Brix) of the juice samples was measured at $20{ }^{\circ} \mathrm{C}$ using ABBE refractometer (WAY-1S Digital Abbe Refractometer, Comecta S.A, Spain). Samples for phenolic compounds', including anthocyanins' determination were prepared in three replicates, approx. $1 \mathrm{~g}$ sample was weighed into $20 \mathrm{~mL}$ UltraTurrax $\AA$ tube and added $50 \%$ ethanol $+1 \% \mathrm{HCl}(\mathrm{v} / \mathrm{v})$ solution, milled using IKA ${ }^{\circledR}$ UltraTurrax ${ }^{\circledR}$ Tube Drive (Germany) for $3 \mathrm{~min}$, treated in ultrasonic bath (Branson 1800, Emerson, USA) for $30 \mathrm{~min}$, the tubes were shaken with multi-rotator (Multi RS-60, Biosan Sia, Latvia) in $30 \mathrm{~min}, 45 \mathrm{rpm}$, and finally centrifuged (refrigerated centrifuge, Sigma Laborzentrifugen $\mathrm{GmbH}$, Germany) at $1000 \mathrm{rpm}(162 * \mathrm{~g})$ for $5 \mathrm{~min}$ at $15{ }^{\circ} \mathrm{C}$. The supernatants were pipetted into $1.5 \mathrm{~mL}$ Eppendorf tubes and centrifuged for $10 \mathrm{~min}$ at 13x1000 rpm using Eppendorf MiniSpin (Eppendorf AG, Germany). Aliquots for chromatographic analysis were pipetted into the vials and the quantification of total phenols and total anthocyanins was performed on UHPLC-DAD ACE Excel 3 C18-PFP $100 \times 2.1 \mathrm{~mm}$ (Shimadzu Nexera X2, Japan) at 280 and 520 $\mathrm{nm}$, respectively. Total polyphenols were expressed as $\mathrm{mg}$ of chlorogenic acid equivalents per $\mathrm{mg} 100 \mathrm{~g}^{-1}$ fresh weight (FW). Total content of anthocyanins was expressed as cyanidin-3-O-glucoside equivalents mg $100 \mathrm{~g}^{-1} \mathrm{FW}$. The named laboratory grade chemicals were used also as external standards purchased from Sigma-Aldrich (Germany).

\subsection{Statistical analysis}

Standard deviations and means were calculated for each characteristic. Differences between the enzyme-treated and nontreated juices and press-residues were considered to be significant at $\mathrm{p}<0.05$ by one- and two-way ANOVA, followed by the Fisher's LSD test. The same letters in columns mark non-significant differences at $\mathrm{p}<0.05$.

\section{Results and discussion}




\subsection{Juice yield}

The used pectinase preparation increased the juice outcome up to $44.3 \%$ when compared to non-treated control (Figure 1). The juice pressing without enzyme maceration was difficult and resulted in puree-like very viscose product which demonstrate the importance of using pectinase treatment for increased juice outcome, as also described by other authors, $[2,11]$. The effect was most evident in cultivars 'Ben Lomond' and 'Karri' which are not typical cultivars for juice extraction. On the contrary to these, 'Pamyati Vavilova' is a common cultivar for juice production due to its suitability for machine harvesting and thin fruit skin, and probably therefore the effect of enzymes was lower, up to $17 \%$. The results were expected, since the enzyme preparation contained multi-purpose pectinase initially developed for use in the juice production. In the fruit juice production, it is necessary to break the water binding capacity of the pectin by its degradation in the primary cell wall and in the middle lamella, which enables maximal juice extraction $[2,11]$. The juice outcome was significantly lower in blackcurrant juices without enzyme treatment, as also described by other authors [11, $12,13,14]$. Therefore, in case of low juice yield, innovative utilization methods for efficient use of press-residues or alternative for the better use of fruit would be required [4].

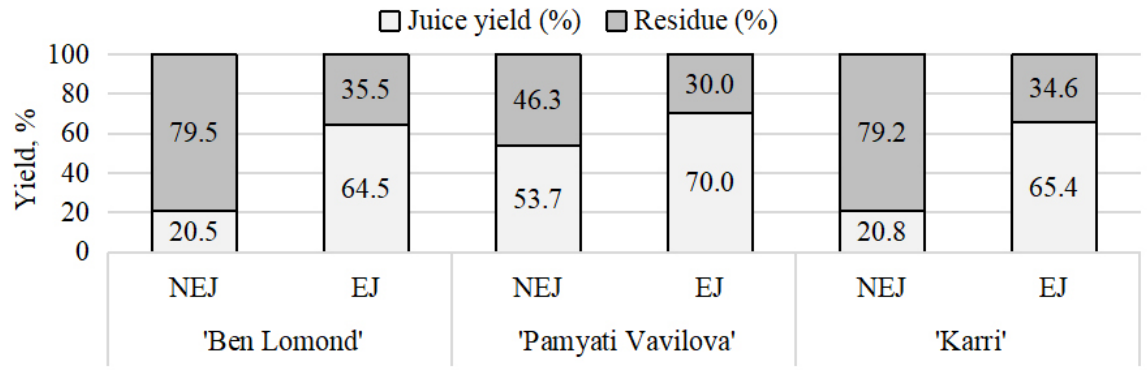

Fig. 1 Blackcurrant juice yield (\%) and press-residue (\%) depending on the enzymatic treatment

Notes: NEJ - non-enzymatic juice; EJ - enzyme-treated juice.

\subsection{Soluble solids content (SSC) in juice}

SSC in blackcurrant juice ranged from 14.3 to $16.0^{\circ} \mathrm{Brix}$ in non-enzyme-treated juice and from 16.0 to $16.7^{\circ} \mathrm{Brix}$ in enzyme-treated juice (Table 1). The variations were cultivar dependent and showed significant effect of enzymatic pretreatment on the soluble solids in juice. The SSC was increased in enzyme-treated juice. Similarly, Laaksonen et al., have reported that in some cultivars, enzymatic treatments of blackcurrant mash prior to juice pressing increase the sugar content in the juices, in some cultivars it may be decreased [13]. On the other hand, Mieszczakowska-Frac et al., found no significant effect of enzyme application on blackcurrant juice soluble solids [14]. In the present study, it could be the result of increased juice production which equally extracted more soluble solids into the juice.

\subsection{Total polyphenols content (TPC)}

The TPCs according to treatments are presented in Table 1. No significant effect of enzyme treatment on TPC was observed in blackcurrant juices. This was unexpected, as increase in value-adding fruit ingredients due to treatment was anticipated. In our experiment, enzyme addition and heat treatment were at minimal level of the range recommended by the product sheet, which may partially explain the relatively low TPC extraction into the juice. The highest TPC was in the juice of cultivar 'Ben Lomond' (up to $352 \mathrm{mg} 100 \mathrm{~g}^{-1} \mathrm{FW}$ ) and in the press-residues of 'Pamyati Vavilova' (up to $\left.538 \mathrm{mg} 100 \mathrm{~g}^{-1} \mathrm{FW}\right)$. Still, similar findings on the absence of the effect of enzyme preparation in black currant juices have been reported by Sandri et al., [16].

However, treated press-residue contained significantly higher amount of total polyphenols when compared to nontreated ones. TPC in residues ranged from 401 to $538 \mathrm{mg} 100 \mathrm{~g} \mathrm{~g}^{-1} \mathrm{FW}$ among the cultivars tested. From three analysed press-residues, the effect of enzymatic treatment was revealed in two cultivars - 'Pamyati Vavilova' and 'Karri' had higher TPC left in their residues. In comparison with three cultivars, the extraction of polyphenols of 'Ben Lomond' was the least affected by the prior-pressing enzyme treatment. The discrepancy between the pectinolytic enzyme preparations in their polyphenol release capacity could be due to differences in their unspecified properties [10, 11]. Therefore, conditions of enzyme use such as treatment time is described to have effect on polyphenols extraction to the end product $[3,14]$. Landbo et al., confirmed that the main pectinolytic activities of some preparations were particularly active at the higher maceration temperatures applied [2]. In the present experiment, different treatment times other than recommended according to product sheet were not tested. 
Table 1. Blackcurrant fruit, juice and press-residue soluble solids ( $\left.{ }^{\circ} \mathrm{Brix}\right)$, total polyphenols $\left(\mathrm{mg} 100 \mathrm{~g}^{-1}\right)$ and total

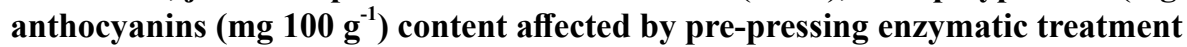

\begin{tabular}{|c|c|c|c|c|c|c|c|}
\hline Cultivar & Variant & \multicolumn{2}{|c|}{$\mathrm{SSC},{ }^{\circ} \mathbf{B x}$} & \multicolumn{2}{|c|}{ TPC, $\mathrm{mg} 100 \mathrm{~g}^{-1}$} & \multicolumn{2}{|c|}{ TAC, $\operatorname{mg} 100 \mathrm{~g}^{-1}$} \\
\hline \multirow{5}{*}{ 'Ben Lomond' } & Fruits & 15,5 & & 404 & $\mathrm{ab}$ & 301 & $\mathrm{ab}$ \\
\hline & NE-Juice & 14,8 & $\mathrm{c}$ & 352 & $a-c$ & 250 & $\mathrm{c}$ \\
\hline & E-Juice & 16,0 & $\mathrm{~b}$ & 344 & $a-c$ & 248 & $\mathrm{c}$ \\
\hline & NE-Residue & n.a & & 465 & $\mathrm{a}$ & 347 & $a b$ \\
\hline & E-Residue & n.a & & 522 & $\mathrm{a}$ & 386 & $\mathrm{a}$ \\
\hline \multirow{5}{*}{ 'Pamyati Vavilova' } & Fruits & 15,8 & & 390 & $\mathrm{c}$ & 307 & $\mathrm{c}$ \\
\hline & NE-Juice & 16,0 & $\mathrm{~b}$ & 320 & $\mathrm{~d}$ & 243 & $\mathrm{~d}$ \\
\hline & E-Juice & 16,7 & $\mathrm{a}$ & 319 & $\mathrm{~d}$ & 238 & $\mathrm{~d}$ \\
\hline & NE-Residue & n.a & & 509 & $\mathrm{~b}$ & 399 & $\mathrm{~b}$ \\
\hline & E-Residue & n.a & & 538 & $\mathrm{a}$ & 422 & $\mathrm{a}$ \\
\hline \multirow{5}{*}{ 'Karri' } & Fruits & 17,3 & & 371 & $\mathrm{c}$ & 258 & $\mathrm{~b}$ \\
\hline & NE-Juice & 14,3 & d & 310 & $\mathrm{~d}$ & 211 & $\mathrm{c}$ \\
\hline & E-Juice & 16,3 & $\mathrm{~b}$ & 308 & $\mathrm{~d}$ & 207 & $\mathrm{c}$ \\
\hline & NE-Residue & n.a & & 401 & $\mathrm{~b}$ & 270 & $\mathrm{~b}$ \\
\hline & E-Residue & n.a & & 497 & $\mathrm{a}$ & 341 & $\mathrm{a}$ \\
\hline
\end{tabular}

Notes: NE-Juice - non-enzyme-treated juice; E-Juice - enzyme-treated juice; NE-Residue - non-enzyme-treated press-residue; E-Residue - enzyme-treated press-residue; n.a - results not available; SSC - soluble solids content; TPC - total polyphenols content; TCY - total anthocyanins; Within the same column, means with different letters are significantly different at $\mathrm{p}<0.05$.

\subsection{Total anthocyanin content (TAC)}

The TACs according to the treatments are presented in Table 1. Similarly to TPC, no significant effect of enzyme treatment on TAC was observed in blackcurrant juices. The highest TAC was in the juice of cultivar 'Ben Lomond' (up

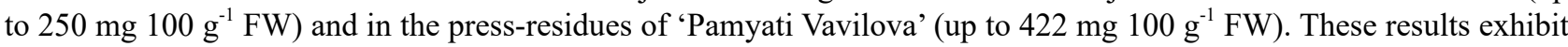
the fact that the enzyme preparation and temperature chosen for pre-pressing enzymatic treatment was not sufficient for extraction of polyphenols, including anthocyanins into the juice. TAC varied from 270 to $422 \mathrm{mg} 100 \mathrm{~g} \mathrm{~g}^{-1} \mathrm{FW}$ among the press-residues of the three experimental cultivars. As expected, the TAC in enzyme-treated press-residues was significantly higher than in non-treated residues, which indicate that press-residue is a valuable source of polyphenols, in particular in case of insufficient enzyme treatment of the blackcurrant mash. Archaina et al., have reported the advantage of high-value waste derived from juice preparation suitable for using as functional food ingredient [17]. Our results revealed that considerable amount of bioactive compounds remained in the press-residue presenting the high potential for utilization of blackcurrant processing by-products.

\section{Conclusions}

The effect on the yield, total polyphenols and total anthocyanin content of black currant juices and press-residue subjected to mash treatments were studied. The results of the laboratory scale juice extraction experiment revealed that enzyme-aided juice pressing enhanced juice outcome, as expected, but did not increase the content of bioactive compounds in juice. This emphasize the importance of selecting the preparation and knowledge on its activities. Polyphenols, incl. anthocyanin extraction into juice was affected rather by cultivar properties than pre-pressing enzyme treatment. Based on the results, in general, cultivars 'Ben Lomond' and 'Pamyati Vavilova' showed somewhat higher 
content of polyphenolic compounds most likely due to their fruit skin properties. Polyphenols content increased up to $29 \%$ in enzymatic press-residue, and anthocyanins decreased up to $18 \%$ in enzyme treated juice in comparison with freshly frozen berries. Our results revealed that significant amount of bioactive compounds remained in the pressresidue presenting the high potential for utilization of blackcurrant processing by-products. Possible alternatives such as microwave- or ultrasound-assisted extractions methods could be executed for increasing the recovery of polyphenolic compounds for product development and other application purposes.

\section{Acknowledgements}

The European Regional Development Fund is gratefully acknowledged for the financing of the research.

\section{References}

[1] Hilz, H., Bakx, E. J., Schols, H. A., \& Voragen, A. G. J. (2005). Cell wall polysaccharides in black currants and bilberries - Characterisation in berries, juice, and press cake. Carbohydrate Polymers, 59(4), 477-488. https://doi. org/10.1016/j.carbpol.2004.11.002

[2] Landbo, A. K., \& Meyer, A. S. (2004). Effects of different enzymatic maceration treatments on enhancement of anthocyanins and other phenolics in black currant juice. Innovative Food Science and Emerging Technologies, 5(4), 503-513. https://doi.org/10.1016/j.ifset.2004.08.003

[3] Kapasakalidis, P. G., Rastall, R. A., \& Gordon, M. H. (2009). Effect of a cellulase treatment on extraction of antioxidant phenols from black currant (Ribes nigrum L.) pomace. Journal of Agricultural and Food Chemistry, 57(10), 4342-4351. https://doi.org/10.1021/jf8029176

[4] Laaksonen, O., Mäkilä, L., Tahvonen, R., Kallio, H., \& Yang, B. (2013). Sensory quality and compositional characteristics of blackcurrant juices produced by different processes. Food Chemistry, 138(4), 2421-2429. https:// doi.org/10.1016/j.foodchem.2012.12.035

[5] Puri, M., Sharma, D., \& Barrow, C. J. (2012). Enzyme-assisted extraction of bioactives from plants. Trends in Biotechnology, 30(1), 37-44. https://doi.org/10.1016/j.tibtech.2011.06.014

[6] Prathyusha, K., \& Suneetha, V. (2011). Bacterial pectinases and their potent biotechnological application in fruit processing/juice production industry: A review. Journal of Phytology, 3(6), 16-19. Retrieved from http://journalphytology.com/index.php/phyto/article/viewArticle/7261

[7] Ribeiro, D. S., Henrique, S. M. B., Oliveira, L. S., Macedo, G. A., \& Fleuri, L. F. (2010). Enzymes in juice processing: A review. International Journal of Food Science and Technology, 45(4), 635-641. https://doi. org/10.1111/j.1365-2621.2010.02177.x

[8] Tapre, A. R., \& Jain, R. K. (2014). Pectinases: Enzymes for fruit processing industry. International Food Research Journal, 21(2), 447-453.

[9] Dal Magro, L., Dalagnol, L. M. G., Manfroi, V., Hertz, P. F., Klein, M. P., \& Rodrigues, R. C. (2016). Synergistic effects of Pectinex Ultra Clear and Lallzyme Beta on yield and bioactive compounds extraction of Concord grape juice. LWT - Food Science and Technology, 72, 157-165. https://doi.org/10.1016/j.lwt.2016.04.046

[10] Heffels, P., Bührle, F., Schieber, A., \& Weber, F. (2017). Influence of common and excessive enzymatic treatment on juice yield and anthocyanin content and profile during bilberry (Vaccinium myrtillus L.) juice production. European Food Research and Technology, 243(1), 59-68. https://doi.org/10.1007/s00217-016-2722-0

[11] Bagger-Jørgensen, R., \& Meyer, A. S. (2004). Effects of different enzymatic pre-press maceration treatments on the release of phenols into blackcurrant juice. European Food Research and Technology, 219(6), 620-629. https:// doi.org/10.1007/s00217-004-1006-2

[12] Bender, C., Killermann, K. V., Rehmann, D., \& Weidlich, H. H. (2017). Effect of mash enzyme and heat treatments on the cellular antioxidant activity of black currant (Ribes nigrum), raspberry (Rubus idaeus), and blueberry (Vaccinium myrtillus) juices. CyTA - Journal of Food, 15(2), 277-283. https://doi.org/10.1080/19476337.2016.124 7914

[13] Laaksonen, O., Sandell, M., Nordlund, E., Heiniö, R. L., Malinen, H. L., Jaakkola, M., \& Kallio, H. (2012). The effect of enzymatic treatment on blackcurrant (Ribes nigrum) juice flavour and its stability. Food Chemistry, 130(1), 31-41. https://doi.org/10.1016/j.foodchem.2011.06.048 
[14] Mieszczakowska-Frac, M., Markowski, J., Zbrzeźniak, M., \& Płocharski, W. (2012). Impact of enzyme on quality of blackcurrant and plum juices. LWT - Food Science and Technology, 49(2), 251-256. https://doi.org/10.1016/ j.lwt.2011.12.034

[15] Mäkilä, L., Laaksonen, O., Kallio, H., \& Yang, B. (2017). Effect of processing technologies and storage conditions on stability of black currant juices with special focus on phenolic compounds and sensory properties. Food Chemistry, 221, 422-430. https://doi.org/10.1016/j.foodchem.2016.10.079

[16] Sandri, I.G., C.M.T. Lorenzoni, R.C. Fontana, ja M. Moura da Silveira. 2013. „Use of pectinases produced by a new strain of Aspergillus niger for the enzymatic." LWT - Food Science and Technology, 51: 469-475. doi:http:// dx.doi.org/10.1016/j.lwt.2012.10.015.

[17] Archaina, D., Leiva, G., Salvatori, D., \& Schebor, C. (2018). Physical and functional properties of spray-dried powders from blackcurrant juice and extracts obtained from the waste of juice processing. Food Science and Technology International, 24(1), 78-86. https://doi.org/10.1177/1082013217729601 